\title{
Endotoxin as a predictor of severe dengue infection
}

\author{
Sri Rezeki H Hadinegoro
}

\begin{abstract}
Systemic acute inflammatory response in endotoxemia promotes circulating disturbances and enhances prolonged and recurrent shock Study on 120 dengue hemorrhagic fever $(D H F)$ patients was conducted to determine the role of endotoxemia in predicting severe dengue infection. Endotoxin concentration in severe dengue infection was 4 times higher than that in DHF in general. The highest endotoxin level among 32 severe dengue cases belonged to prolonged and recurrent shock cases. Patients with endotoxemia had 5.8 times chance to develop severe dengue infection with shock than than those without endotoxemia. Other predictors for severe dengue infection with shock included time (duration) of shock recovered, fibrinogen concentration, serum $C 4$, and nutritional status; while platelets count was the only predictor for severe dengue infection without shock. Serum endotoxin level of $15 \mathrm{pg} / \mathrm{ml}$ was the cut-off point of severe dengue infection. In severe dengue infection, better prognosis is characterized by time of shock recovered within 48 minutes, fever ceased within two days, and gastrointestinal bleeding of not more than two days of hospitalization.
\end{abstract}

\begin{abstract}
Abstrak
Respons sistemik pada inflamasi akut pada endotoksemia, menyebabkan gangguan sirkulasi dan memacu terjadinya shok berkepanjangan dan syok berulang. Telah dilakukan penelitian pada 120 orang anak yang menderita demam berdarah dengue (DBD), untuk membuktikan apakah endotoksemia merupakan faktor prediktor untuk infeksi dengue berat. Kadar endotoksin serum pada infeksi dengue berat 4 kali lebih tinggi dari pada infeksi dengue pada umumnya. Diantara 32 orang anak dengan infeksi dengue beral, syok berkepanjangan dan syok berulang mempunyai nilai endotoksin serum yang paling tinggi. Risiko kelompok infeksi dengue dengan endotoksemia untuk menderita infeksi dengue berat adalah 5.8 kali lebih tinggi dari pada kelompok infeksi dengue yang tidak menderita endotoksemia. Faktor prediktor untuk menjadi infeksi berat pada infeksi dengue kelompok syok adalah waktu yang dipergunakan untuk mengatasi syok, kadar fibrinogen, kadar serum C4, endotoksemia, dan status nutrisi; sedangkan pada kelompok non-syok, jumlah trombosit merupakan satu-satunya faktor prediktor. Kadar endotoksin serum $15 \mathrm{pg} / \mathrm{ml}$ merupakan cut-off untuk infeksi dengue berat. Prognosis baik apabila syok dapat teratasi kurang dai 48 menit tidak lebih dari 64 menit, demam turun dalam dua hari, dan perdarahan saluran cerna tidak melebihi dua hari perawatan.
\end{abstract}

Keywords: endotoxin, predictor, severe dengue infection

Epidemiological changes of dengue infection in Indonesia has been emerged since fatal cases of dengue infection were reported in Jakarta and Surabaya in 1969. 'Thereafter, dengue cases have been increasingly reported from almost all provinces in Indonesia, followed by increased mortality in severe dengue cases. ${ }^{2}$ Shock syndrome occurred in $16-40 \%$ of hospitalized dengue infection patients with markedly higher mortality than that of patients without shock. Fatal cases were mainly associated with shock and its complication, e.g. prolonged and recurrent shock due to gastrointestinal bleeding. The mortality rate in

Department of Child Health, Faculty of Medicine, University of Indonesia, Dr. Cipto Mangunkusumo Hospital Jakarta. Indonesia prolonged and recurrent shock case $(66.7 \%)$ was higher than that shock without complication $(13.0 \%){ }^{3}$

Immunological changes are considered to be the basic pathogenesis of dengue infection. According to Bhamarapravati ${ }^{4}$ cell host damage is caused by either direct or indirect immunological process as well as combination of both. Monocytes, macrophages, and Kupffer cells are the target cells of dengue infection in human. In secondary dengue infection, immune complexes enter the circulation and then activate complement system which can promote hypovolemic shock. Platelet aggregation and coagulation factors are also activated by immune complex. Among those pathways, complement system is the important cause pathway in shock syndrome. ${ }^{5}$ In addition, other mediators i.e. cytokines and endotoxin could take a role in shock 
syndrome. ${ }^{6}$ Shock syndrome in dengue infection is the primary pathogenesis in severe DHF, all other organ damage is secondary to shock. ${ }^{7}$ Endotoxin is a polysaccharide component of outer capsule of Gram negative bacteria. It is suggested that in dengue shock syndrome endotoxin enters blood circulation from gut flora due to intestinal ischemia. ${ }^{8,9}$ In our previous report, the proportion of endotoxemia in dengue hemorrhagic fever cases is about $63 \%$, shock group has higher proportion than that non-shock group dengue cases. ${ }^{10}$ Acute inflammation, either local or systemic is the defense mechanism in human response to endotoxin. ${ }^{11}$ Via systemic response endotoxin promotes shock and enhances prolonged/recurrent shock in dengue infection. This study was conducted to determine predictors to severe dengue infection with specific reference to the role of endotoxin, as an effort to reduce dengue case fatality rate.

\section{METHODS}

\section{Study population}

This was a cross sectional study of 120 patients with severe dengue infection hospitalized in Department of Child Health Dr. Cipto Mangunkusumo Hospital Jakarta between March 1993 and March 1995. All patients meeting the study criteria were included in the study (consecutive sampling). Patients with incomplete data (missing complement or fibrinogen examination due to hemolysis of the specimen and insufficient blood volume) were excluded from analysis. Similarly, patients who suffered from bacterial infection were also excluded.

\section{Clinical and laboratory data}

The diagnosis was established by WHO clinical criteria, and was confirmed with the hemagglutination test and / or Dengue Blot test. Data of the following outcomes were recorded: (1) Time of defervescence (fever ceased), calculated from admission until body temperature reached below $37.5^{\circ} \mathrm{C}$, (2) Time of shock recovered, calculated from admission until shock recovered, and (3) Time of gastrointestinal bleeding disappeared, calculated from the beginning to the end of gastrointestinal bleeding. Laboratory data included hemoglobin content, hematocrit value, WBC, differential count, platelet count, serum complement concentration to $\mathrm{C} 3$ and $\mathrm{C} 5$, fibrinogen, endotoxin, and serum cytokine (TNF- $\alpha$ and IL-6) concentration.

\section{Statistical analyses}

Chi-squared tests was used to analyze nominal data, correlation statistic was used for ordinal variables. The two main outcome variables were endotoxemia and severe dengue infection. Logistic regression was used to analyze the relationship of the dependent variable i.e., severe dengue infection (nominal, dichotomous), with the independent variables (predictors), i.e., nutritional status (nominal), type of infection (nominal, dichotomous), time of shock recovered (numeric), platelet count (numeric), serum $\mathrm{C} 3$ concentration (numeric), serum endotoxin concentration (numeric), serum TNF- $\alpha$ concentration (numeric), and serum IL6 concentration (numeric). The cut-off point of endotoxin concentration was determined by calculating sensitivity and specificity by constructing a receiver operating characteristic curve (ROC).

\section{RESULTS}

\section{Subject characteristics}

Of the 120 patients studied, only 93 patients were analyzed; the rest were excluded because of lack of C3, $\mathrm{C} 4$, and fibrinogen examination due to hemolysis or insufficient blood specimen. The characteristics of the subjects with complete and incomplete data were similar with respect to age group, nutritional status, degree of the illness, severity of dengue infection, and prognosis, as shown in Table 1.

Sixty-four (53.3\%) of patients had shock and 32 $(26.6 \%)$ had severe dengue infection, i.e., prolonged shock (15 patients), recurrent shock (7), gastrointestinal bleeding of more than 2 days (16), and encephalopathy (6) patients. Death occurred in nine patients.

\section{Endotoxemia}

Endotoxemia (defined as serum endotoxin concentration of more than $9.8 \mathrm{pg} / \mathrm{ml}$ ) occurred in $76(63.3 \%$ ) of patients, $28(50 \%)$ of them were from shock group and $48(75 \%)$ from non-shock group. Dengue shock syndrome had three times higher risk to develop endotoxemia than the non-shock group (Odds ratio 3.0; 95\% CI 1.30; 7.00; p value 0.008).

\section{Nutritional status}

The proportion of shock in patients with dengue infection having good nutrition was higher than that in 
Table 1. Sample characteristics

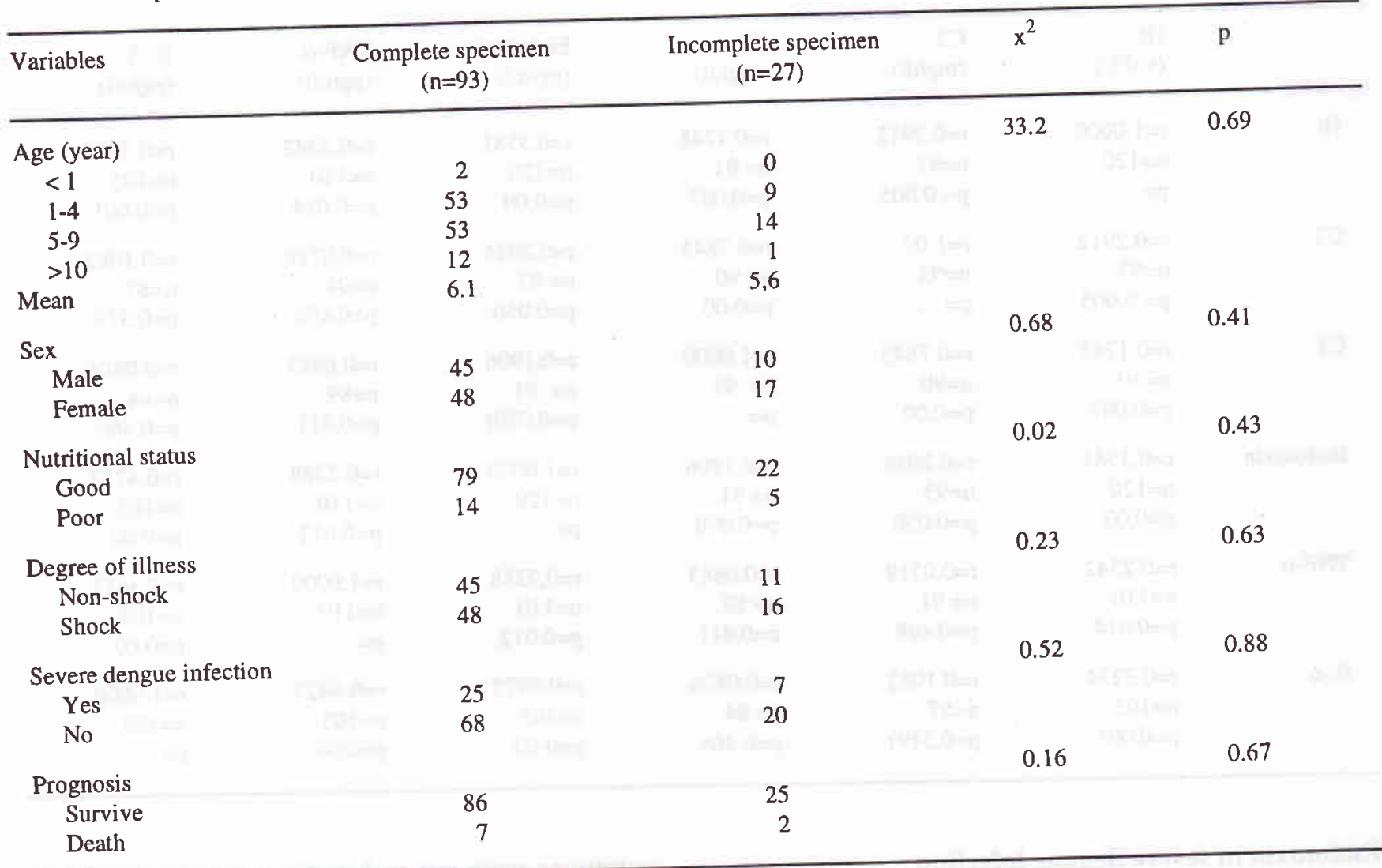

patients with less well-nourished; patients with good nutrition had 3.9 times more chance to experience shock compared to those with lower nutritional status (Odds ratio 3.9; 95\% CI 1.20; 13.7; $\mathrm{x}^{2}=5.39$; MantelHaenzel p-value 0.020). On the contrary, no significant association was found between the nutritional status and endotoxemia. The Odds ratio of patients with good nutritional status to have endotoxemia was $1.3(95 \%$ CI $0.41-4.29 ; \mathrm{p}=0.80$ ) compared to those with low nutritional status. This was supported by the finding that the median serum endotoxin concentration in both groups, i.e., good and lower nutritional status) was similar $(5.4 \mathrm{pg} / \mathrm{ml})$.

\section{Cytokine assay}

Tumor necrosis factor alfa (TNF- $\alpha$ ) and IL-6 were examined in each degree of dengue infection. In grade I non-shock group, the median serum TNF- $\alpha$ concentration was still low $(9.8 \mathrm{pg} / \mathrm{ml})$, while increased serum level found in grade II non-shock and grade III shock groups, the levels were 31.0 and $26.0 \mathrm{pg} / \mathrm{ml}$, respectively. Serum TNF- $\alpha$ concentration increased with the severity of the disease, the highest TNF- $\alpha$ level was found in grade IV shock group (profound shock). The median serum IL-6 in grades I and II was in the lower limit concentration, i.e., 3.4 and $4.2 \mathrm{pg} / \mathrm{ml}$ respectively, while in grades III and IV (shock group) serum IL-6 levels increased to 9.0 and $8.7 \mathrm{pg} / \mathrm{ml}$ respectively.

\section{Correlations of hematocrit, $\mathrm{C} 3, \mathrm{C} 4$, endotoxin, TNF- $\alpha$ and IL-6}

In this series a weak correlation was observed between serum endotoxin and TNF- $\alpha$ concentration in dengue infection $(r=0.24)$ and while the correlation between endotoxin and IL-6 concentration was fairly strong $(r=0.68)$. Table 2 showed that there was no correlation between endotoxin concentration with $\mathrm{C} 3(\mathrm{r}=0.20)$ and $\mathrm{C} 4(\mathrm{r}=0.19)$. In contrast, there was a fairly strong correlation between the cytokines (TNF- $\alpha$ and IL-6) and complements (C3 and $\mathrm{C} 4$ ), i.e., $r=0.64$ and $r=$ 0.78 , respectively. 
Table 2. Correlation between hematocrit, endotoxin, C3, C4, TNF- $\alpha$, and IL- 6

\begin{tabular}{|c|c|c|c|c|c|c|c|c|}
\hline & & $\begin{array}{l}\mathrm{Ht} \\
\text { (vol\%) }\end{array}$ & & $\begin{array}{l}\text { C3 } \\
(\mathrm{mg} / \mathrm{dl})\end{array}$ & $\begin{array}{l}\mathrm{C} 4 \\
(\mathrm{mg} / \mathrm{dl})\end{array}$ & $\begin{array}{l}\text { Endotoxin } \\
(\mathrm{pg} / \mathrm{ml})\end{array}$ & $\begin{array}{l}\text { TNF- } \alpha \\
(\mathrm{pg} / \mathrm{ml})\end{array}$ & $\begin{array}{l}\text { IL-6 } \\
(\mathrm{pg} / \mathrm{ml})\end{array}$ \\
\hline $\mathrm{Ht}$ & & $\begin{array}{l}r=1.0000 \\
n=120 \\
p=\end{array}$ & & $\begin{array}{l}\mathrm{r}=0.2912 \\
\mathrm{n}=93 \\
\mathrm{p}=0.005\end{array}$ & $\begin{array}{l}r=0.1748 \\
n=91 \\
p=0.097\end{array}$ & $\begin{array}{l}r=0.3581 \\
n=120 \\
p=0.00\end{array}$ & $\begin{array}{l}\mathrm{r}=0.2342 \\
\mathrm{n}=110 \\
\mathrm{p}=0.014\end{array}$ & $\begin{array}{l}r=0.3234 \\
n=105 \\
p=0.001\end{array}$ \\
\hline C3 & & $\begin{array}{l}r=0.2912 \\
n=93 \\
p=0.005\end{array}$ & & $\begin{array}{l}\mathrm{r}=1.00 \\
\mathrm{n}=93 \\
\mathrm{p}=\end{array}$ & $\begin{array}{l}\mathrm{I}=0.7845 \\
\mathrm{n}=90 \\
\mathrm{p}=0.00\end{array}$ & $\begin{array}{l}r=0.2036 \\
n=93 \\
p=0.050\end{array}$ & $\begin{array}{l}r=0.0719 \\
n=91 \\
p=0.498\end{array}$ & $\begin{array}{l}r=0.1082 \\
n=87 \\
p=0.319\end{array}$ \\
\hline $\mathrm{C} 4$ & & $\begin{array}{l}r=0.1748 \\
n=91 \\
p=0.097\end{array}$ & & $\begin{array}{l}r=0.7845 \\
n=90 \\
p=0.00\end{array}$ & $\begin{array}{l}\mathrm{r}=1.0000 \\
\mathrm{n}=91 \\
\mathrm{p}=\end{array}$ & $\begin{array}{l}\mathrm{r}=0.1906 \\
\mathrm{n}=91 \\
\mathrm{p}=0.070)\end{array}$ & $\begin{array}{l}\mathrm{r}=0.0883 \\
\mathrm{n}=89 \\
\mathrm{p}=0.411\end{array}$ & $\begin{array}{l}r=0.0806 \\
n=84 \\
p=0.466\end{array}$ \\
\hline Endotoxin & & $\begin{array}{l}r=0.3581 \\
n=120 \\
p=0.00\end{array}$ & & $\begin{array}{l}r=0.2036 \\
n=93 \\
p=0.050\end{array}$ & $\begin{array}{l}r=0.1906 \\
n=91 \\
p=0.070\end{array}$ & $\begin{array}{l}r=1.0000 \\
n=120 \\
p=\end{array}$ & $\begin{array}{l}\mathrm{r}=0.2388 \\
\mathrm{n}=110 \\
\mathrm{p}=0.012\end{array}$ & $\begin{array}{l}r=0.4772 \\
n=105 \\
p=0.00\end{array}$ \\
\hline TNF- $\alpha$ & & $\begin{array}{l}r=0.2342 \\
n=110 \\
p=0.014\end{array}$ & & $\begin{array}{l}r=0.0719 \\
n=91 \\
p=0.498\end{array}$ & $\begin{array}{l}r=0.0883 \\
n=89 \\
p=0.411\end{array}$ & $\begin{array}{l}r=0,2388 \\
n=110 \\
p=0.012\end{array}$ & $\begin{array}{l}r=1.0000 \\
n=110 \\
p=.\end{array}$ & $\begin{array}{l}r=0.3427 \\
n=103 \\
p=0.00\end{array}$ \\
\hline IL-6 & & $\begin{array}{l}r=0.3234 \\
n=105 \\
p=0.001\end{array}$ & & $\begin{array}{l}r=0.1082 \\
n=87 \\
p=0.319)\end{array}$ & $\begin{array}{l}r=0.0806 \\
n=84 \\
p=0.466\end{array}$ & $\begin{array}{l}r=0.6872 \\
n=105 \\
p=0.00\end{array}$ & $\begin{array}{l}r=0.6427 \\
n=103 \\
p=0.00\end{array}$ & $\begin{array}{l}\mathrm{r}=1.0000 \\
\mathrm{n}=105 \\
\mathrm{p}=.\end{array}$ \\
\hline
\end{tabular}

\section{Endotoxin in severe dengue infection}

The median endotoxin concentration in severe dengue infection was 20.9 (range $0-180$ ) $\mathrm{pg} / \mathrm{ml}$, higher than that in dengue infection in general, i.e., 5.4 (range $0-180) \mathrm{pg} / \mathrm{ml}$. Among 32 patients with severe dengue infection, prolonged and recurrent shock had the highest serum endotoxin level, i.e., 22.6 and 24.1 $\mathrm{pg} / \mathrm{ml}$ respectively, while the levels in severe gastrointestinal bleeding, encephalopathy, and death patients were $10.7,4.7$, and $17.1 \mathrm{pg} / \mathrm{ml}$, respectively.

\section{Predictors in severe dengue infection}

The risk of patients with endotoxemia for having severe dengue infection was 5.8 times higher than in patients without endotoxemia cases (Odds ratio 5.8; $95 \%$ CI $1.72 ; 21.72 ; \mathrm{p}=0.00194$ ).

\section{Group of severe dengue infection with shock}

To examine the role of endotoxemia as a predictor in severe dengue infection a multivariate analysis was done. Nutritional status, type of infection, $\mathrm{C} 3$ and $\mathrm{C} 4$ levels, platelet, fibrinogen, time of shock recovered, presence of hemoconcentration, TNF- $\alpha$, and IL- 6 con- centrations were put in logistic regression model in non-shock and shock group. Using the step-wise logistic regression analysis, it was found that time of shock recovered, fibrinogen and $\mathrm{C} 4$ levels, endotoxemia, nutritional status, IL- 6 and TNF- $\alpha$ levels, hemoconcentration, and platelet count fit to the model. In other words, time of shock recovered, fibrinogen, $\mathrm{C} 4$, endotoxemia, and nutritional status were predictors in severe dengue infection, but serum IL-6 was not.

It is interesting to note that good nutritional status, which in the bivariate analysis had nearly 4 times higher to develop shock than lower nutritional status, in logistic regression analysis had an exp B of $-0,0628$, meaning that good nutritional status could prevent severe dengue infection.

\section{Group of severe dengue infection without shock}

The predictors in the non-shock group were quite different from those in the shock group. Platelet count was the only variable which significantly fit to this model $(p=0,002)$ although it was not clinically significant (exp. $\mathrm{B}=1.000$ ). Endotoxemia was not statistically significant ( $\mathrm{p}=0.0594$ ), as were as serum fibrinogen, $\mathrm{C} 4$, nutrition, IL-6, TNF- $\alpha$, and hemoconcentration. 
Table 3. Predictors in shock group severe dengue infection

\begin{tabular}{lccccccc}
\hline Independent Variable & $\mathrm{B}$ & $\mathrm{SE}$ & Wald & df & Sig (p) & $\mathrm{R}$ & Exp(B) \\
\hline Time of shock recovered & -0.1119 & 0.0345 & 10.5446 & 1 & $0.0012^{*}$ & 0.3292 & 0.8941 \\
Fibrinogen & 0.0233 & 0.0101 & 5.3580 & 1 & $0.0206^{*}$ & 0.2064 & 0.9770 \\
C4 & 0.1021 & 0.0493 & 4.2924 & 1 & $0.0383^{*}$ & 0.1705 & 1.1075 \\
Endotoxemia & 0.7408 & 0.3591 & 4.2549 & 1 & $0.0391^{*}$ & 0.1678 & 2.0976 \\
Gizi & -2.7682 & 1.4382 & 3.7049 & 1 & $0.0543^{*}$ & $0.1470-$ & 0.0628 \\
IL-6 & 0.0030 & 0.0118 & 0.0647 & 1 & 0.0599 & 0.2042 & 0.9970 \\
TNF- $\alpha$ & 0.0006 & 0.0020 & 0.0785 & 1 & 0.7794 & 0.0000 & 0.9994 \\
Hemoconcentration & 0.0098 & 0.0307 & 0.1021 & 1 & 0.7494 & 0.0000 & 0.9903 \\
Trombocytopenia & 0.0120 & 0.0075 & 2.5476 & 1 & 0.4773 & 0.0000 & 1.0000 \\
Constanta & 9.20069 & 3.3976 & 7.3433 & 1 & 0.0067 & & \\
\hline
\end{tabular}

$* \mathrm{p} \leq 0,05$

Table 4. Predictors in non-shock group severe dengue infection

\begin{tabular}{lrrrrrrr}
\hline Independent Variable & B & SE & Wald & df & Sig (p) & R & Exp(B) \\
\hline Trombocytopenia & 1.0799 & 0.4418 & 5.9756 & 1 & $0.0201^{*}$ & 0.2042 & 1.0000 \\
Endotoxaemia- & 0.4475 & 0.8402 & 0.2837 & 1 & 0.0594 & 0.2514 & 0.6392 \\
C4 & 0.4475 & 0.1240 & 0.7169 & 1 & 0.3971 & 0.0000 & 0.9003 \\
Nutritional status & -10.9412 & 66.9807 & 0.0267 & 1 & 0.8702 & 0.0000 & 0.0000 \\
IL-6 & 0.1921 & 0.2539 & 0.5724 & 1 & 0.4493 & 0.0000 & 0.8252 \\
TNF- $\alpha$ & 0.0009 & 0.0153 & 0.0035 & 1 & 0.9527 & 0.0000 & 1.0009 \\
Hemoconcentration & 0.0898 & 0.1062 & 0.7151 & 1 & 0.3978 & 0.0000 & 0.8252 \\
Fibrinogen & 0.0117 & 0.0155 & 0.5698 & 1 & 0.4504 & 0.0000 & 0.9884 \\
Constanta & 17.2393 & 67.4142 & 0.0654 & 1 & 0.7982 & & \\
\hline
\end{tabular}

${ }^{*} \mathrm{p} \leq 0,05$

\section{Cut-off point of serum endotoxin concentration}

The cut-off point of endotoxin concentration was calculated by sensitivity and specificity test on $10,12,15$, 18 , dan $20 \mathrm{pg} / \mathrm{ml}$ endotoxin concentration as shown in Table 5. At the cut-off point endotoxin level of 15 $\mathrm{pg} / \mathrm{ml}$, the sensitivity, specificity, PPV and NPV were $78.3,68.2,47.0$, and $89.1 \%$, respectively. The sensitivity, specificity values of serum endotoxin concentration at $15 \mathrm{pg} / \mathrm{ml}$ were drawn in the receiver operating characteristic (ROC) in Figure 1.

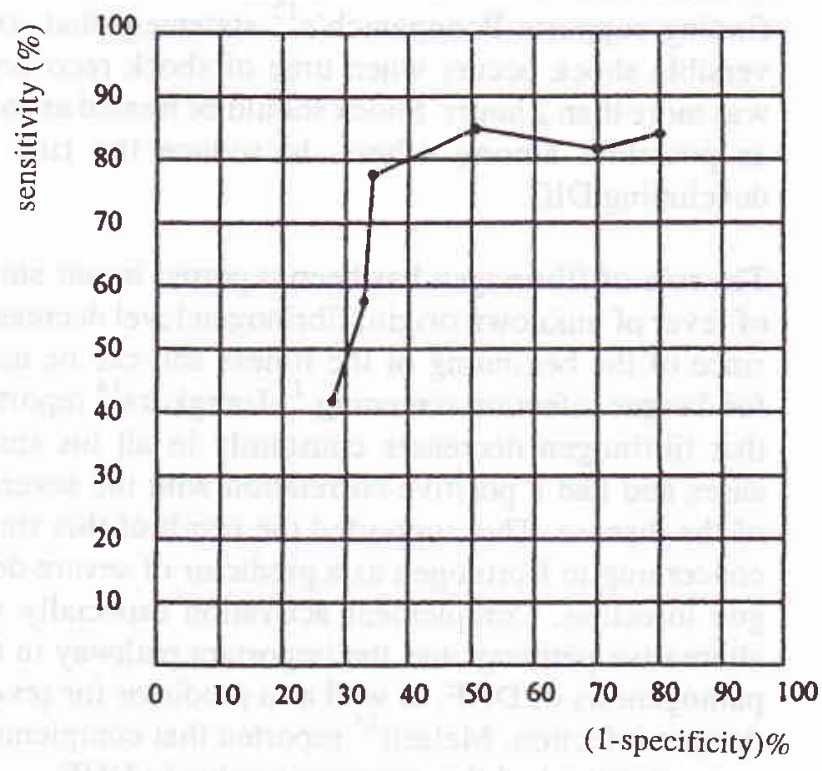

Figure I. Receiver operating characteristic curve 
Table 5. Sensitivity, specificity, positive predictive value, and negative predictive value

\begin{tabular}{ccccc}
\hline $\begin{array}{c}\text { Serum Endotoxin } \\
(\mathrm{pg} / \mathrm{ml})\end{array}$ & $\begin{array}{c}\text { Sensitivity } \\
(\%)\end{array}$ & $\begin{array}{c}\text { Specificity } \\
(\%)\end{array}$ & $\begin{array}{c}\text { Positive } \\
\text { predictive } \\
\text { value (\%) }\end{array}$ & $\begin{array}{c}\text { Negative } \\
\text { predictive } \\
\text { value (\%) }\end{array}$ \\
\hline 10 & 42.3 & 72.9 & 42.1 & 51.9 \\
12 & 56.9 & 68.4 & 47.0 & 77.4 \\
15 & 78.3 & 68.2 & 47.0 & 89.1 \\
18 & 81.1 & 44.9 & 61.4 & 73.5 \\
20 & 80.9 & 21.7 & 61.6 & 66.2 \\
\hline
\end{tabular}

\section{DISCUSSION}

This study shows endotoxin as a single predictor in severe dengue infection. DHF patients with endotoxemia had five times (in bivariate analysis) or twice (in logistic regression analysis) higher risk to have severe dengue infection than those who without endotoxemia. Endotoxemia is not the only predictor in severe dengue infection; confounding factors should be considered in the clinical setting.

Concerning to the pathogenesis of dengue infection, predictors in shock group were different from those in non-shock group. The predictors for severe dengue infection in shock group were time of shock recovered, fibrinogen, C4, endotoxemia, and nutritional status. Duration of shock recovered was the important predictor in severe dengue infection. In this study, the time of shock recovered was 48.0 minutes (SD 26.6). This finding supports Pongpanich's ${ }^{12}$ statement that irreversible shock occurs when time of shock recovered was more than 2 hours. Shock should be treated as soon as possible, among others, to reduce the risk of developing DIC.

The role of fibrinogen has been reported in our study of fever of unknown origin; fibrinogen level decreases since of the beginning of the illness and can be used for dengue infection screening. ${ }^{13}$ Isangkura ${ }^{14}$ reported that fibrinogen decreases constantly in all his study cases and had a positive correlation with the severity of the disease. This supported the result of this study concerning to fibrinogen as a predictor of severe dengue infection. Complement activation especially via alternative pathway was the important pathway in the pathogenesis of DHF, as well as a predictor for severe dengue infection. Malasit ${ }^{15}$ reported that complement concentration had the prognostic value in DHF.

Nutritional status plays a role in immune response against infection. This study revealed that patients with good nutritional status had a higher risk to develop shock than those with lower nutritional status. This series shows that nutritional status also played a role in the production of TNF- $\alpha$. In patients with a good nutritional status, TNF- $\alpha$ concentration was lower than that in low nutritional status, but endotoxin and IL-6 production were not. These findings suggest that nutrition plays a direct role in immune complex production or when the virus enters the monocytes/macrophages at the early stage of dengue infection. The role of nutrition on the cytokine production in dengue infection needs further studies. Increased IL-6 as well as endotoxin concentrations simultaneously were proved as predictors in severe dengue infection. It supports the role of negative feed back IL- 6 due to increased TNF- $\alpha$ level. On the other hand, IL-6 and high endotoxin level could be found in the circulation. In this series, the role of $I \mathrm{~L}-6$ as a predictor in severe dengue infection was not proved statistically; larger sample size is probably needed to confirm this finding. In conclusion, endotoxemia has two times more in risk to have severe dengue infection together with other factors such as time of shock recovered, fibrinogen concentration, $\mathrm{C} 4$ value, endotoxemia, and nutritional status.

This series shows that platelet count was a predictor to severe dengue infection without shock, but endotoxemia was not. Platelet is one of target cells in dengue infection, which causes changes in platelet number and function. The decrease of platelet count has a positive association with shock; therefore platelet has a prognostic value. On the other hand, endotoxin concentration in the non-shock group was below the cut-off point, leading to suggest that endotoxemia has no influence in severe dengue infection without shock. Serum TNF- $\alpha$ was not proven as a predictor in severe dengue infection, although the role of TNF- $\alpha$ could not be ignored in the course of the disease. Further studies are needed to determine the cut-off of the acceleration of endotoxin-TNF-IL6 pathway. This finding has an important value with regard to case management. Sriskandar reported unsatisfactory result on the use of anti-endotoxin drug.

Endotoxemia was detected both in DHF and severe DHF cases. To predict severe dengue infection, the cut-off endotoxin concentration should be pointed out. With the cut-off point of $15 \mathrm{pg} / \mathrm{ml}$, the sensitivity and specificity to predict severe dengue infection were $78.3 \%$ and $68.2 \%$ respectively, while the positive and negative predictive values were $47.0 \%$ and $89.1 \%$, respectively. It means that endotoxemia is good enough to predict severe dengue infection at the level of $<15 \mathrm{pg} / \mathrm{ml}$. In contrast, serum endotoxin of $\mathrm{pg} / \mathrm{ml}$ 
predicts $89.1 \%$ that a patient does not suffer from severe dengue infection.

One study on twenty septic shock adult patients has shown that serum endotoxin concentration does not increase while TNF- $\alpha$ and IL- 6 are detected in all cases at a very high level. ${ }^{16}$ Other study shows that fatal septic cases have a very high IL-6 level while the TNF- $\alpha$ concentration is the same both in survivors or those who die. ${ }^{17}$ It can be concluded, that in septic cases serum IL- 6 can be used for endotoxemia detection as well as a prognostic value. The same situation was found in 6 fatal cases in this study; all of the 6 patients had a very high TNF- $\alpha$ and Il- 6 concentration, suggesting endotoxemia as cause of death followed by increased TNF- $\alpha$ and $\Pi-6$ concentrations.

To sum up, this study shows that time of shock recovered, levels of fibrinogen and $\mathrm{C} 4$, presence of endotoxemia, nutritional status, and interleukin-6 level are the predictors of severe dengue infection with shock, while thrombocytopenia is the only predictor for severe dengue infection without shock. Patients with dengue infection can be predicted to develop severe clinical manifestations such as recurrent or prolonged shock, severe bleeding, or encephalopathy at serum endotoxin level $15 \mathrm{pg} / \mathrm{ml}$ or more. Good prognostic signs for dengue infection include recovery of shock within 48 minutes, fever ceases within two days of hospitalization, gastrointestinal bleeding of no more than two days, and good nutritional status.

\section{REFERENCES}

1. Sumarmo. Masalah demam berdarah dengue di Indonesia. Presented at National Workshop on Dengue Fever/ Dengue Haemorrhagic Fever. Jakarta, 24-26 November 1998.

2. Suroso T. Epidemiologi dan penanggulangan penyakit DBD di Indonesia saat ini. Presented at National workshop on Dengue Fever/ Dengue Haemorrhagic Fever. Jakarta, 24-26 November 1998.

3. Hadinegoro SR. Demam berdarah dengue: pengalaman di Bagian Ilmu Kesehatan Anak RS Dr Ciptomangunkusumo Jakarta. Cermin Dunia Ked 1992; 81: 57-61.
4. Bhamarapravati N. Pathogenesis of dengue hemorrhagic fever. Presented at The International Symposium on Dengue and Dengue Hemorrhagic Fever. Bangkok, 1-3 Oktober 1990.

5. Suvatte V. Immunological aspects of dengue haemorrhagic fever: studies in Thailand. South Asian J Trop Med Pub Hlth 1987 ; 18: 312-5.

6. Hadinegoro SR. Plasma endotoxin study on dengue hemorrhagic fever cases. In: Hadinegoro SR, Inada K. eds. Proceedings on one day seminar on endotoxin. Jakarta: University of Indonesia Press 1994: 27-34.

7. Nimmannitya S. Clinical manifestations of dengue/dengue haemorrhagic fever. In: Thongchaeron P, ed. Monograph on dengue/dengue haemorrhagic fever. New Delhi: World Health Organization Regional Office for South-East Asia.Regional Publication 1993; 22: 48-54

8. Suffredini AF. Endotoxin administration to human. In: Lamy M, Thijs, LG.ed; Mediators of sepsis. Berlin: Springer Verlag, 1992: 13-20.

9. Haglund U. Systemic mediators released from the gut in critical illness. Critical Care Med 1993; S15-8.

10. Hadinegoro SR. Telaah endotoxaemia pada perjalanan penyakit demam berdarah dengue: perhatian khusus pada syok, produksi TNF-a, interleukin-6, dan sebagai faktor predictor demam berdarah dengue berat. Disertasi Doktor Ilmu Kedokteran. Program Pascasarjana, Fakultas Kedokteran Universitas Indonesia. Jakarta 1996.

11. Van Deventer SJH, Buller HR, Ten Cate JW, Sturk A, Pauw $W$. Endotoxaemia an early predictor on septicemia in febrile patients. Lancet 1988; 605-8.

12. Pongpanich B. Hemodynamic changes in shock associated with dengue haemorhagic fever. Southeast Asian J Trop Med Pub Health 1987; 18: 326-30.

13. Hadinegoro SR. Prevention and control bleeding in dengue haemorhagic fever. ICMR Annals 1988; 8: 312-8.

14. Isarangkura $\mathbf{P B}$, Pongpanich $B$, Pintadit $P$, Planichyakam: Haemostatic dearrangement in dengue haemorrhagic fever. South East Asian J Trop Med Pub HIth 1989; 20: 325-30.

15. Malasit P, Mongkolsapaya, Nimmannitya S, Suvatte S. Complement in dengue hemorrhagic fever/ dengue shock syndrome. In: of the the XIII International Congress for Tropical Medicine and Malaria. Pattaya, 29 November - 4 Desember 1992.

16. Hack CE, Nuijens JH, Van Schijndel SV, Abbink JJ, Erenberg AJM, Thijs IG. A model for the interplay of inflammatory mediators in sepsis a study in 48 patients. Crit Care Med 1990; 16: 187-91.

17. Endo S, Inada K, Yoshida M. Endotoxin and cytokines in patients with gastrointestinal tract perforation. Mediators of Inflammation 1992; 1: 45-8. 